\title{
JNPH
}

Volume 5 No. 2 (Desember 2017)

(C) The Author(s) 2017

\section{KOMUNIKASI TERAPEUTIK PERAWAT DENGAN TINGKAT KECEMASAN ANAK USIA PRASEKOLAH (3-5 TAHUN) SELAMA PEMASANGAN INFUS}

\author{
THERAPEUTIC COMMUNICATION OF NURSES WITH ANXIETY LEVEL OF \\ PRESCHOOL CHILDREN DURING INFUSION
}

\author{
DWI WULANDARI, FITRIANA \\ SEKOLAH TINGGI ILMU KESEHATAN DEHASEN BENGKULU \\ Program Studi Ners STIKes Dehasen \\ Email: Dwiwulandari3599@gmail.com
}

\begin{abstract}
ABSTRAK
Penyakit dan rawat inap sering menjadi isu krisis pada anak-anak. Selain itu, anak-anak yang dirawat di rumah sakit juga mendapat terapi infus yang sangat rentan terhadap kecemasan terkait dengan tindakan invasif. Selama pelaksanaan infus, seseorang sering merasa cemas terutama pada anak-anak karena takut akan tindakan seorang perawat. Komunikasi Terapeutik Perawat dengan Tingkat Kecemasan Anak Prasekolah (3-5 tahun) Selama Instalasi Infus di Instalasi Gawat Darurat Rumah Sakit Dr. M. Yunus Bengkulu pada tahun 2017. Metode penelitian yang digunakan adalah penelitian deskriptif dengan rancangan cross-sectional. Populasi adalah semua perawat yang ada di ruang Dr. DR. Rumah sakit M. Yunus Bengkulu pada 2017 sebanyak 27 perawat. Teknik sampling yang digunakan adalah teknik total sampling sehingga jumlah sampel sebanyak 27 orang. Hasil penelitian menunjukkan bahwa hampir separuh responden $(40,7 \%)$ memiliki tingkat kecemasan yang parah, lebih dari separuh responden $(59,3 \%)$, mendapat komunikasi terapeutik yang baik dari perawat dan ada hubungan antara komunikasi terapeutik perawat dengan tingkat kecemasan usia prasekolah (3-5 tahun) selama infus intravena di Unit Gawat Darurat Rumah Sakit Dr. M. Yunus Bengkulu pada tahun 2017 ( $\mathrm{p}=0,019)$. Dianjurkan ke rumah sakit Dr. M. Yunus Bengkulu untuk meningkatkan kualitas layanan keperawatan kepada anak sehingga anak-anak yang menjalani perawatan dapat menunjukkan kecemasan ringan atau tidak cemas dengan cara membuat peraturan kepada perawat untuk menerapkan pendekatan perawatan atraumatik pada anak-anak, terutama pada penerapan komunikasi terapeutik.
\end{abstract}

Kata kunci: instalasi infus, kecemasan anak

\begin{abstract}
Diseases and hospitalization often become a crisis issue in children. In addition, hospitalized children also on average receive infusion therapy that is very susceptible to anxiety associated with invasive action. During the execution of infusion, a person often feel anxious especially in children for fear of the actions of a nurse. The purpose of this research was to know the correlation between Therapeutic Communication of Nurses with Anxiety Level of Preschool Children (3-5 years) During Infusion Installation at Emergency Department of Dr. M. Yunus Hospital Bengkulu in 2017. The research method used was a descriptive research using crosssectional design. The population were all nurses who exists in the space of Dr. DR. M. Yunus
\end{abstract}


hospital Bengkulu in 2017 as many as 27 nurses. The sampling technique used was the total sampling technique so that the number of samples was 27 people. The results of this research indicated that almost half of the respondents $(40,7 \%)$, had severe anxiety level, more than half of respondents $(59,3 \%)$, got good therapeutic communication from nurse and there was correlation between nurse's therapeutic communication with anxiety level of preschool age (3-5 years) during intravenous infusion at Emergency Department of Dr. M. Yunus Hospital Bengkulu in 2017(p = 0.019). Recommended to the hospital of Dr. M. Yunus Bengkulu to improve the quality of nursing services to children so that children undergoing treatment can show mild anxiety or no anxiety by way of making regulations to nurses to apply atraumatic care approach in children, especially on the application of therapeutic communication.

\section{Keywords: infusion installation, child's anxiety}

\section{PENDAHULUAN}

Masalah kesehatan anak merupakan salah satu masalah dalam bidang kesehatan diseluruh dunia termasuk di Indonesia. Derajat kesehatan anak mencerminkan derajat kesehatan bangsa, sebab anak sebagai generasi penerus bangsa memiliki kemampuan yang dapat dikembangkan dalam meneruskan pembangunan bangsa. Berdasarkan masalah tersebut masalah kesehatan anak diprioritaskan dalam perencanaan atau penataan pembangunan (Hidayat, 2009).

Masa anak-anak adalah masa dasar yang sesungguhnya dalam menjalani kehidupan, meskipun seluruh masa anak-anak merupakan masa dasar namun banyak ahli yang berkeyakinan bahwa penyesuaian diri yang kurang baik pada masa dewasa bermula dari pengalaman-pengalaman masa kanak-kanak yang kurang baik selain itu juga dipercaya bahwa cara bayi diperlakukan akan menentukan tingkah lakunya dalam memandang dunia sebagai suatu yang aman dan dapat dipercaya, atau sebaliknya sebagai ancaman (Marimbi, 2010).

Menurut Wong (2009), penyakit dan hospitalisasi sering kali menjadi masalah krisis pada anak. Terutama selama tahuntahun awal, sangat rentan terhadap krisis penyakit dan hospitalisasi yang dapat disebabkan oleh kecemasan yang utama pada anak-anak yang mengalami hospitalisasi adalah adanya perpisahan dengan orang tua, tidak bisa mengendalikan diri, adanya cedera pada tubuh, serta nyeri. Hal ini dipengaruhi oleh beberapa faktor antara lain usia perkembangan, pengalaman sebelumnya tentang penyakit, perpisahan dengan orang tua, hospitalisasi, kemampuan dalam mekanisme pertahanan diri, tingkat keparahan penyakit, serta system pendukung yang tersedia.

Selain itu anak menjalani hospitalisasi juga rata-rata mendapat terapi pemasangan infus yang sangat rentan terhadap kecemasan yang berhubungan dengan tindakan invasif. Terapi intravena (IV) merupakan teknologi yang paling sering digunakan dalam pelayanan kesehatan di seluruh dunia. Lebih dari $60 \%$ pasien yang masuk ke rumah sakit mendapat terapi melalui IV. Tindakan Pemasangan infus tentu saja akan menimbulkan nyeri dan rasa sakit pada anak. Hal ini tentunya juga akan menimbulkan trauma pada anak sehingga anak akan mengalami kecemasan (Nelson, 1999, dalam Yeli, 2015).

Tindakan pemasangan infus pada anak bukan merupakan hal yang mudah karena anak memiliki vena yang kecil dan rapuh, sehingga sering ditemui pemasangan infus yang berulang kali karena gagal memasang kanul intra vena. Pemasangan infus juga biasanya dilakukan berkali-kali pada anak selama anak dalam masa perawatan karena anak cenderung tidak bisa tenang sehingga infus yang sedang terpasang sering macet, aboket bengkok/patah atau bahkan infus terlepas. Akibatnya anak akan dilakukan pemasangan infus berulang kali dan dapat menimbulkan rasa cemas, takut, dan rasa tidak nyaman akibat nyeri yang dirasakan 
setiap kali penusukan. Hal ini juga akan menimbulkan trauma pada anak sehingga anak akan mengalami kecemasan dan stress (Nelson, 1999, dalam Maretno, 2015).

Mulyono, (2008) dikutip oleh Winokan (2015), saat pelaksanaan tindakan pemasangan infus seseorang sering merasakan cemas terutama pada anak-anak karena takut dengan tindakan dari seorang perawat. Cemas adalah suatu reaksi emosional terhadap penilaian individu yang tidak memiliki objek yang spesifik. Kecemasan dapat dimanifestasikan dengan perasaan khawatir, gelisah, takut, tidak tentram yang disertai berbagai keluhan fisik.

Respon cemas yang ditunjukkan anak saat perawat melakukan tindakan pemasangan infus sangat bermacam-macam, ada yang bertindak agresif, bertindak dengan mengekspresikan secara verbal, membentak, serta dapat bersikap dependen yaitu menutup diri dan tidak kooperatif. Kurangnya komunikasi terapeutik perawat terhadap anak yang akan dilakukan pemasangan infus membuat tingkat kecemasan anak semakin tinggi. Hal demikian tidak akan terjadi apabila sejak dari pertama kali pasien masuk rumah sakit, perawat mampu memberikan pengertian dan pendekatan yang terapeutik kepada pasien dan keluarganya (Winokan, 2015).

Berdasarkan data jumlah kunjungan pasien anak di RSUD. Dr. M. Yunus Bengkulu menunjukkan bahwa jumlah kunjungan pasien anak setiap tahunnya mengalami peningkatan. Dengan adanya peningkatan kunjungan ini perlu diadakan upaya penanganan kepada anak dengan menggunakan komunikasi yang terapeutik sebagai upaya meminimalkan adanya kecemasan maupun stress akibat hospitalisasi maupun prosedur invasive seperti pemasangan infus.

Berdasarkan latar belakang yang di uraikan diatas peneliti berkeinginan melakukan penelitian dengan judul "Hubungan Komunikasi Terapeutik Perawat dengan Tingkat Kecemasan Anak Usia Prasekolah (3-5 tahun) selama pemasangan infus di ruang IGD RSUD. Dr. M. Yunus Bengkulu”.

\section{METODE PENELITIAN}

Jenis penelitian ini adalah penelitian secara analitik dengan menggunakan desain cross-sectional. Populasi dalam penelitian ini adalah seluruh perawat pelaksana yang ada di ruang IGD RSUD Dr. M. Yunus Bengkulu tahun 2017 sebanyak 27 orang. Pengumpulan data penelitian dilakukan dengan melakukan pengamatan kepada anak saat dilakukan pemasangan infus oleh perawat untuk melihat tingkat kecemasan anak selain itu peneliti juga melakukan pengamatan kepada setiap perawat IGD saat melakukan pemasangan infus kepada pasien anak prasekolah yang observasi tingkat kecemasannya, untuk mendapatkan data tentang komunikasi terapeutik perawat. Prosedur observasi pada perawat maupun anak prasekolah ini dilakukan sampai 27 sampel terpenuhi. Setelah data semua diperoleh selanjutnya data diolah dan dianalisis dengan menggunakan analisis univariat dan analisis bivariat.

\section{HASIL PENELITIAN}

Tabel 1 Distribusi frekuensi tingkat kecemasan anak usia prasekolah (3-5 tahun) selama pemasangan infus di Ruang IGD RSUD. Dr. M. Yunus Bengkulu Tahun 2017

\begin{tabular}{ccc}
\hline $\begin{array}{c}\text { Tingkat Kecemasan } \\
\text { Anak }\end{array}$ & Frekuensi & Persentase \\
\hline Kecemasan Berat & 11 & 40,7 \\
\hline Kecemasan Sedang & 9 & 33,3 \\
\hline Kecemasan Ringan & 7 & 25,9 \\
\hline Total & 27 & 100,0 \\
\hline
\end{tabular}

Berdasarkan tabel 1 diketahui bahwa hampir dari sebagian responden $(40,7 \%)$, mempunyai tingkat kecemasan berat.

Tabel 2 Distribusi frekuensi komunikasi terapeutik perawat pada anak usia prasekolah (3-5 tahun) selama pemasangan 
infus di ruang IGD RSUD. Dr. M. Yunus Bengkulu Tahun 2017

\begin{tabular}{ccc}
\hline $\begin{array}{c}\text { Komunikasi } \\
\text { Terapeutik }\end{array}$ & Frekuensi & Persentase \\
\hline Kurang baik & 11 & 40,7 \\
\hline Baik & 16 & 59,3 \\
\hline Total & 27 & 100,0 \\
\hline
\end{tabular}

Berdasarkan tabel 2 diketahui bahwa lebih dari setengah responden (59,3\%), mendapat komunikasi terapeutik yang baik dari perawat.

Tabel 3 Hubungan komunikasi terapeutik perawat dengan tingkat kecemasan anak usia prasekolah (3-5 tahun) selama pemasangan infus di ruang IGD RSUD. Dr. M. Yunus Bengkulu Tahun 2017

\begin{tabular}{|c|c|c|c|c|c|c|c|c|}
\hline Variabel & Kec & & $\operatorname{asan} A$ & An & & & & \\
\hline Komunika & Berat & & lang & $\mathbf{R i}$ & ingan & & otal & \\
\hline Гerap & $\begin{array}{ll}\text { f } \% \\
\end{array}$ & & $\%$ & $\mathbf{f}$ & $\%$ & 1 & $\%$ & \\
\hline Kurang & 872,7 & & 18,2 & 1 & 9,1 & 11 & 100 & \\
\hline Baik & 318,8 & - & 43,8 & 6 & 37,5 & 16 & $\overline{100}$ & 0,01 \\
\hline
\end{tabular}

Berdasarkan tabel 3 diketahui bahwa hasil analisis chi-square menunjukkan bahwa nilai $p=0,019$ lebih kecil dari nilai alpha 0,05 artinya ada hubungan komunikasi terapeutik perawat dengan tingkat kecemasan anak usia prasekolah (3-5 tahun) selama pemasangan infus di Ruang IGD RSUD. Dr. M. Yunus Bengkulu tahun 2017.

\section{PEMBAHASAN}

Hasil analisis bivariat menggunakan analisis chi-square menunjukkan bahwa nilai $p=0,019$ lebih kecil dari nilai alpha 0,05 artinya ada hubungan komunikasi terapeutik perawat dengan tingkat kecemasan anak usia prasekolah (3-5 tahun) selama pemasangan infus di Ruang IGD RSUD. Dr. M. Yunus Bengkulu tahun 2017. Hasil penelitian ini menunjukkan bahwa komunikasi terapeutik merupakan salah satu faktor yang dapat berpengaruh terhadap tingkat kecemasan pada anak yang menjalani hospitalisasi, terutama pada anak yang akan dilakukan pemasangan infus.

Hasil penelitian ini sesuai dengan pendapat Hidayat, (2009) yang menyatakan bahwa komunikasi terapeutik merupakan hal yang sangat penting dalam menurunkan kecemasan anak saat pemasangan infus maka dari itu perawat dituntut untuk menerapkan komunikasi terapeutik yang baik pada anak. Maka tindakan yang dilakukan dalam mengatasi masalah kecemasan pada anak, apapun bentuknya harus berlandaskan pada prinsip atraumatik care atau asuhan yang terapuetik. Salah satu tindakan keperawatan Atraumatic care adalah dengan menggunakan komunikasi terapeutik sebagai upaya perawatan yang tidak menimbulkan trauma pada anak. Perawatan tersebut juga difokuskan dalam pencegahan terhadap trauma yang merupakan bagian dalam keperawatan anak.

Hasil penelitian ini sesuai dengan penelitian Winokan, (2015) dengan judul hubungan komunikasi terapeutik perawat dengan tingkat kecemasan anak usia 5-12 tahun dalam pelaksanaan pemasangan infus diruang perawatan anak RSUD Lapangan Sawang Kabupaten Kepulauan Sitaro, menunjukkan bahwa sebagian besar komunikasi terapeutik perawat yaitu termasuk pada kategori cukup sedangkan kecemasan anak pada sebagian besar responden adalah kecemasan sedang. Dari hasil uji statistic Spearman Rho didapat nilai koefisien korelasi sebesar $(\mathrm{r})=0,580$ dengan signifikan $(\mathrm{p}=$ 0,000). Kesimpulan penelitian ini adalah komunikasi terapeutik perawat berhubungan dengan kecemasan anak dalam persiapan pelaksaan pemasangan infus. Semakin baik komunikasi maka semakin menurunnya kecemasan anak dalam persiapan pemasangan infus.

Berdasarkan hasil penelitian ini dan beberapa teori yang telah dikemukakan bahwa peneliti berasumsi bahwa semakin baik komunikasi terapeutik dilakukan sebelum pemasangan infus maka akan semakin menurunya kecemasan anak terhadap tindakan tersebut. Hal ini dapat terjadi karena 
informasi yang diberikan perawat melalui komunikasi terapeutik dapat meningkatkan kepercayaan anak, serta meningkatkan kedekatan anak dengan perawat dimana anak akan merasa lebih nyaman dan yakin kalau apa yang dilakukan adalah untuk kesembuhannya.

\section{KESIMPULAN}

1. Bahwa hampir dari sebagian responden, mempunyai tingkat kecemasan berat.

2. Lebih dari setengah responden, mendapat komunikasi terapeutik yang baik dari perawat.

3. Ada hubungan komunikasi terapeutik perawat dengan tingkat kecemasan anak usia prasekolah (3-5 tahun) selama pemasangan infus di ruang IGD RSUD. Dr. M. Yunus Bengkulu tahun 2017 $(p=0,019)$.

\section{SARAN}

1. RSUD. Dr. M. Yunus Bengkulu

Kepada pihak RSUD. Dr. M. Yunus Bengkulu diharapkan dapat meningkatkan kualitas pelayanan keperawatan kepada anak sehingga anak yang menjalani perawatan dapat menunjukkan kecemasan yang ringan maupun tidak ada kecemasan dengan cara membuat peraturan kepada perawat untuk menerapkan pendekatan perawatan atraumatik care pada anak terutama pada penerapan komunikasi terapeutiknya.

2. Kepada peneliti selanjutnya

Kepada peneliti selanjutnya diharapkan agar berupaya lebih mengembangkan dan memperdalam bahasan tentang faktor yang mempengaruhi kecemasan pada anak yang menjalani hospitalisasi dengan mempertimbangkan faktor lain seperti adanya trauma masa lalu, peran orang tua, keadaan lingkungan. Penelitian ini menggunakan data wawancara yang mendalam sehingga hasil yang dicapai dapat lebih baik lagi.

\section{DAFTAR PUSTAKA}

Arifin. 2015. hubungan antara komunikasi terapeutik perawat dengan perilaku kooperatif anak usia prasekolah yang mengalami hospitalisasi di Bangsal Anggrek RSUD Kota Salatiga. Skripsi. Stikes Kusuma Husada Surakarta

Damayanti. 2008. Komunikasi Terapeutik dalam Praktik Keperawatan. PT. Refika Aditama: Bandung.

Hidayat. 2008. Pengantar Kebutuhan Dasar Manusia : Aplikasi Konsep dan Proses

Hidayat. 2008. Pengantar Kebutuhan Dasar Manusia : Aplikasi Konsep dan Proses Keperawatan. Jakarta: Salemba Medika

Hidayat. 2009. Pengantar Ilmu Kesehatan Anak. Salemba medika: Jakarta.

Hidayat. 2012. Metode Penelitian Kebidanan Teknik Analisa Data. Salemba Medika: Jakarta

Henwil, 2013. Hubungan komunikasi terapeutik perawat dengan stres hospitalisasi pada anak usia sekolah 6 -12 tahun di irina e blu rsup prof. Dr. $R$. D. Kandou manado. Program Studi Ilmu Keperawatan Fakultas Kedokteran Universitas Sam Ratulangi Manado

Johnson, J.Y. 2010. Prosedur Klinis Keperawatan. Ed-5. EGC: Jakarta.

La ode, 2012. Konsep Dasar Keperawatan. Nuha Medika : Yogyakarta

Marimbi. 2010. Tumbuh Kembang, Status Gizi Dan Imunisasi Dasar Balita. Nuha Medika: Yogyakarta.

Mundakir. 2008. Komunikasi keperawatan. Graha Ilmu: Yogyakarta.

Maretno. 2015. Pelaksanaan Atraumatic Care dalam Pemasangan Infus pada Anak yang Mengalami Rawat Inap di Rumah Sakit Umum Daerah dr. Pirngadi Medan. Skripsi. Fakultas Keperawatan Universitas Sumatera Utara: Medan

Nasrullah. 2016. Buku Ajar Keperawatan Gerontik jili 1, dengan Pendekatan Asuhan Keperawatan NANDA NIC dan $N O C$. Trans Info Media : Jakarta 
Nursalam. 2008. Asuhan keperawatan bayi dan anak, Salemba Medika: Jakarta.

Potter\&Perry. 2009. Buku Ajar Fundamental Keperawatan, Konsep, Proses dan Praktik. EGC. Jakarta

Sibagariang. 2010. Buku Saku Metodologi Penelitian Untuk Mahasiswa Diploma Kesehatan. Trans Info Media: Jakarta

Setyorini. 2008. Skill Labs. Medika Fakultas Kedokteran UGM. Yogyakarta

Stuart. 2007. Buku saku keperawatan jiwa: EGC. Jakarta.

Sinaga. 2013. Komunikasi Terapeutik Perawat Pada Anak Usia Sekolah Yang Mendapatkan Tindakan Invasif di RSUP. H. Adam Malik. Skripsi. Fakultas Keperawatan Universitas Sumatera Utara: Medan

Supartini. Y. 2012. Konsep dasar keperawatan anak. EGC: Jakarta.

Siregar. 2013. Hubungan Komunikasi Terapeutik Perawat Terhadap Tingkat Stres Hospitalisasi Anak Usia Sekolah (6-12 TAHUN) Di Ruang III RSUD Dr. Pirngadi Medan. Skripsi. Program Studi S1 Keperawatan Fakultas Keperawatan Universitas Sumatera Utara

Videbeck. 2008. Buku Ajar Keperawatan Jiwa: EGC. Jakarta.

Wayunah. 2011. Hubungan Pengetahuan Perawat Tentang Terapi Infus Dengan Kejadian Plebitis Dan Kenyamanan Pasien Di Ruang Rawat Inap Rumah Sakit Umum Daerah (RSUD) Kabupaten Indramayu. Tesis. Program Pascasarjana Magister Ilmu Keperawatan. Departemen Keperawatan Medikal Bedah Universitas Indonesia. Depok.

Winokan, 2015. Hubungan Komunikasi Terapeutik Perawat Dengan Tingkat Kecemasan Anak Usia 5-12 Tahun Dalam Pelaksanaan Pemasangan Infus Diruang Perawatan Anak Rsud Lapangan Sawang Kabupaten Kepulauan Sitaro. Buletin Sariputra, Oktober 2015 Vol. 5 (3)

Wong. 2009. Buku Ajar Keperawatan Pediatrik. EGC: Jakarta

Yulinda. 2015. Perbedaan Efektifitas Terapi
Musik Klasik Dan Relaksasi Nafas Dalam Terhadap Penurunan Tingkat Kecemasan Pasien Di Ruang High Care Unit (hcu) RSUD Prof. Dr. Margono Soekarjo Purwokerto. Program Studi Keperawatan S1 Fakultas Ilmu Kesehatan Universitas Muhammadiyah Purwokerto

Yeli. 2015. Pengaruh Teknik Guided Imagery Pada Pemasangan Infus Terhadap Kecemasan Anak Usia Sekolah Di RSUD Dr.Pirngadi Medan. Skripsi. Fakultas Keperawatan Universitas Sumatera Utara: Medan 